TECHNICAL TRANSACTIONS 7/2017

CZASOPISMO TECHNICZNE 7/2017

CIVIL ENGINEERING

DOI: $10.4467 / 2353737$ XCT.17.109.6650

\author{
Anna Śpiewak (aspiewak@bud.czest.pl) \\ Małgorzata Ulewicz \\ Department of Organization and Technology Building, Faculty of Civil Engineering, \\ Czestochowa University of Technology
}

\title{
ANALYSIS OF THE IMPACT OF CORROSION ON LOSS OF LOAD CAPACITY AND TIME BETWEEN FAILURES OF A BRIDGE IN THE TOWN OF WISLA
}

\section{ANALIZA WPŁYWU KOROZJI NA SPADEK NOŚNOŚCI ORAZ CZAS}

\author{
BEZAWARYJNEJ PRACY MOSTU W WIŚLE
}

\begin{abstract}
This article presents guidelines developed by the Research Institute of Roads and Bridges for estimating the loss of the load capacity and determining the time between failures of steel road bridges resulting from corrosion. Mathematical relationships which enable the determination of load capacity and durability of bridge structures were discussed. Reduction coefficients required to calculate the percentage decrease of the load bearing capacity of the corroded structure and reduction coefficients that are significant in determining the degree to which lifespan of the structure is shortened were defined. Mathematical algorithms of presented method made it possible to obtain information, that are necessary for further maintenance and possible modernization of the bridge in Wisla.

Keywords: corrosion, steel girders of bridge structures, loss of load capacity of a bridge structure, time between failures of
\end{abstract} structure due to corrosion

\section{Streszczenie}

W artykule przedstawiono wytyczne opracowane przez Instytut Badawczy Dróg i Mostów dotyczące szacowania utraty nośności oraz określania czasu bezawaryjnej pracy stalowych, drogowych obiektów mostowych z uwzględnieniem zjawiska korozji. Omówiono zależności matematyczne pozwalające na wyznaczenie nośności i trwałości konstrukcji mostowych. Scharakteryzowano współczynniki redukcyjne niezbędne do obliczenia procentowego spadku nośności skorodowanej konstrukcji oraz istotne wspólczynniki zmniejszające pozwalające na określenie czasu bezawaryjnej pracy konstrukcji. Algorytmy matematyczne przedstawionej metody pozwolity na uzyskanie danych, które są niezbędne do dalszego utrzymania oraz ewentualnej modernizacji mostu wWiśle.

Słowa kluczowe: korozja, stalowe dźwigary główne obiektów mostowych, utrata nośności konstrukcji mostowych, czas bezawaryjnej pracy konstrukcji 


\section{Introduction}

Technical inspections are very important in the context of bridge maintenance. Technical inspections, maintenance and servicing of bridges need to be performed in order to determine safety risks to users, to maintain the appropriate technical condition and esthetic design of the bridge, to prevent deterioration of the mechanical properties and ensure the efficiency of the durability of bridge structures. The system of inspection of road and bridge structures include: ongoing reviews, annual fundamental reviews, extended reviews every five years and detailed reviews. To analyse the percentage loss of the load capacity of steel girders and determine the time between structural failures due to corrosion, it is necessary to carry out a detailed inspection. Detailed inspections and visual inspection of all elements of construction and execution of basic measurements and tests provide data and information which is necessary for analysing the capacity and durability of the steel girders of the bridge structure. The detailed review report of the technical condition of the bridge on the Wisla (shared by the Management for Provincial Roads in Katowice) allowed for calculations according to the method of the Research Institute of Roads and Bridges (IBDiM). Calculations made using the method of the Road and Bridge Research Institute provided results that are complementary to detailed inspection and additional information on the load bearing capacity (strength of the structure, the stress and loss of material) and durability of structural steel elements. Calculations can help to provide the methods necessary for the modernisation of the bridge or can help in choosing the corrosion protection of structures. In addition, the results of calculations enable the determination of the time between failures of all bridge structures due to corrosion and this results of calculations also enables the identification of strategies that will ensure the ongoing safe use of the bridge structure [1].

\section{An analytical approach to assessing the load capacity of a bridge structure which has been damaged by corrosion}

The decrease in structural load bearing capacity related to the reduction of the crosssectional area of a steel member is caused by the corrosive loss of steel. The loss of material in the solid-web girder cross-section is calculated by measuring the thickness reduction of the cross-section in the upper and lower flanges of the girders and their webs. Measurement of the corrosion loss in bridge members and decks in the form of a steel orthotropic plate is taken considering the width of the deck subpanel defined in accordance with PN-EN 19932:2010 standard [2]. When the load bearing capacity reduction of corroded structure is being calculated the corrosion phenomena should be taken into account as it is often developed in the orthotropic plate longitudinal and transversal stiffeners. The reduction measurement is taken when the $\mathrm{u}_{7}$ - reduction coefficient is applied. Estimating the loss resulting from the undesirable influence of corrosion on the thickness of the cross-sections subjected to bending moments consists of measuring the extent of the identified calibration distance (Fig. 1), where, according to the structural analysis, there is the maximum stress. The result 
of the measurement is the smallest value of the cavity in the $25 \mathrm{~mm}$ measuring points, which they must be cleaned of corrosion products on the circuit of the element [3-6]. Corrosion phenomenon changes the cross-sectional geometry which is why the second moment of area and indicators of the corroded cross-sectional resistance should be calculated taking into account another position of the neutral axis of a steel profile. In accordance with the method recommended by the Road and Bridge Research Institute, it is important to determine the corrosion value of the $i$-th bridge girder - this is calculated relative to the upper and lower fibres of the cross-section with formulas [3]:

$$
\begin{aligned}
& w_{\text {id }}=\frac{W_{\text {id_cor }}}{W_{\text {id_nom }}} \\
& w_{\text {ig }}=\frac{W_{\text {ig_cor }}}{W_{\text {ig_nom }}}
\end{aligned}
$$

where:

$$
\begin{aligned}
& w_{i d}, w_{i g} \\
& W_{\text {id_cor }}, W_{\text {ig_cor }}
\end{aligned}
$$

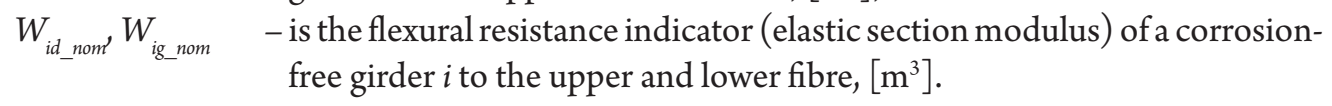$$
\text { - is the corrosive girder parameter } i \text {; }
$$$$
\text { - is the flexural resistance indicator (elastic section modulus) of a corroded }
$$$$
\text { girder } i \text { to the upper and lower fibre, }\left[\mathrm{m}^{3}\right] \text {; }
$$

For further calculations, the minimum value of each corrosive parameters, should be applied.In addition, the cross-sectional areas of the corroded web of girders and transverse stiffeners located at the support points should be determined and then, according to the formula (3),they should be compared with the areas of uncorroded cross-sections. For further analysis assumes the smallest value of the parameter $a_{i}$ the most corroded girders [3-4].

$$
a_{i}=\frac{A_{i_{-} \text {cor }}}{A_{i_{-} \text {nom }}}
$$

where:

$a_{i} \quad-$ is the corrosive parameter of the cross-section in the support $i$;

$A_{i_{-} \text {cor }}-$ is the area of the corroded cross-section in the support $i,\left[\mathrm{~m}^{2}\right]$;

$A_{i \_n o m}^{i-c o r}-$ is the area of the not corroded cross-section in the support $i,\left[\mathrm{~m}^{2}\right]$.

The next stage is to select reduction coefficients which are characterised by susceptibility to changes with regard to the geometry and strength of the cross-sections of the steel elements of the bridge structures. The load capacity of a structure depends on the degree of corrosion of each girder and their interaction when the service load is being transferred. The presented analytical method describes seven dependencies to which the Road and Bridge Research Institute developed reduction coefficients. Of equal importance are: the number of main girders $\left(u_{1}\right)$; the spacing of main girders in their cross-section $\left(u_{2}\right)$; deck type $\left(u_{3}\right)$; transversal bracing type $\left(u_{4}\right)$; transversal bracing concentration along the structure length excluding 
support bracing $\left(u_{5}\right)$; degree of corrosion in transversal bracing $\left(u_{6}\right)$; corrosion degree in transversal stiffeners orthotropic plate longitudinal $\left(u_{7}\right)$. The chosen coefficients enable the identification of the percentage of decrease of the load capacity of a steel road bridge structure $\left(\mathrm{S}_{\mathrm{M}}\right)$ due to the bending moment with particular consideration to corrosion [3]:

$$
S_{M}=\left[1-\frac{\min \left(\sum_{(i=1)}^{k} w_{i d}, \sum_{(i=1)}^{k} w_{i g}\right)}{k} \cdot \prod_{(j=1)}^{n} u_{j}\right] \cdot 100 \%
$$

where:

$S_{M} \quad$ - is the load capacity decrease due to the bending moment, [\%];

$w_{i \ell^{\prime}} w_{i g}$ - is the corrosion parameters of the girder $i=1, \ldots, k$;

$u_{j} \quad-$ is the reduction coefficient $j=1, \ldots, n$;

$k \quad-$ is the number of girders.

To determine the ultimate loss of the structural load bearing capacity caused by corrosion, the load decrease associated with the support's reaction needs to be determined $\left(S_{P}\right)$ [3] - this is achieved using the formula:

$$
S_{P}=\left[1-a_{i} \cdot \prod_{j=1}^{n} u_{j}\right] \cdot 100 \%
$$

where:

$S_{P}$ - is the load capacity decrease due to the support reaction, [\%];

$a_{i}$ - is the corrosion parameter of the most corroded girder $i$;

$u_{j}-$ is the reduction coefficients $j=1, \ldots, n$,

Formulas (4) and (5) enable the identification of a decrease to the total load capacity of a bridge with solid web steel girders $\left(S_{U}\right)$ resulting from the destructive phenomenon of corrosion [3], which is described with the formula (6):

$$
S_{U}=\max \left\{S_{M}, S_{P}\right\}
$$

where:

$S_{U}$ - is the load capacity decrease of the solid web girder due to corrosion phenomenon, [\%].

An analytical approach to assessing the durability of a bridge structure which has been damaged by corrosion

Estimation of the impact of corrosion on the durability of bridge structures requires, above all, the analysis of the object and determining the type and extent of corrosion on the construction. It is important to determine the location of corrosion on the surface of the load bearing capacity steel elements because irregular distribution of corroded elements and the resulting decreases in the mass of the material in cross-sections of the bearing elements causes concentration of stresses. Variable tensions intensify the corrosion process, which accelerates 
the fatigue of structural material. In the method developed by the Road and Bridge Research Institute, the reduction coefficients of durability and mathematical formulas are used - this enables the lifetime of a corroded bridge to be determined $[3,7,8]$. To determine the reduction coefficients, it is necessary to analyse technical and material data relating to the steel-concrete bridge structure, because reduction coefficients are related to: the level of aggressiveness of the environment $\left(S_{A}\right)$; bridge location; type of corrosion in the load capacity structure $\left(K_{R}\right)$; the technical condition of bridge drainage system $\left(T_{W}\right)$, dilatation system $\left(T_{D}\right)$ and insulation system $\left(T_{I}\right)$. The appropriate selection of reduction coefficients enables calculation of the degree to which the lifespan of the constriction has been shortened by corrosion $\left(S_{T}\right)[3]$ :

$$
S_{T}=K_{R} \cdot S_{A} \cdot \frac{T_{W}+T_{I}+T_{D}}{3}
$$

where:

$S_{T} \quad-$ is the degree of shortening of the lifespan of the construction;

$K_{R}, S_{A^{\prime}}, T_{W}, T_{I}, T_{D}$ - is the reduction coefficients.

The next step is to determine the $\beta$ coefficient related to the road class and the age of the analysed bridge $(W)$. It is also obligatory to the projected life span of the bridge $\left(T_{m}\right)$. According to the Polish procedure developed by the Road and Bridge Research Institute, these parameters $\left(S_{T}, \beta, W\right.$ and $\left.T_{m}\right)$ are used to determine the time between failures of the structure due to corrosion $\left(T_{e}\right)$, during which corrosion proceeds with a probability of about $90 \%$ [3]:

$$
T_{e}=T_{m} \cdot S_{T} \cdot \beta-W
$$

where:

$T_{e}-$ is the time between failures of structure due to corrosion, [years];

$T_{m}^{e}$ - is the projected lifespan of the bridge structure, [years];

$S_{T}^{m}$-is the degree of shortening of the lifespan of the construction;

$\beta$ - is reduction coefficient;

$W-$ is the age of the analysed bridge structure, [years].

Analysis of the load capacity and durability of the steel girders of the bridge structure in Wisla. The triple-span beam bridge shown below was analysed. This bridge is located in Wisla and is situated over the Mailnka steam (Fig. 1). This bridge is part of the inter-regional road DW942 managed by the Management for Provincial Roads in Katowice.

The load capacity structure of this bridge is made up of steel beams comprising a rolled profile connected to a concrete slab. In the cross-section, there are four IN340 girders spaced every $1.80 \mathrm{~m}$. The bridgeheads and pillars of the bridge are reinforced concrete, solidwall structures. Additional elements of the bridge are steel safety barriers, the road surface comprised of asphalt concrete, and the bridge drainage system [9].

Based on an analysis of the detailed review report of the technical condition of the bridge on the Wisla [9] and the local detailed inspection of this bridge (Fig. 2 a-d), the values of 


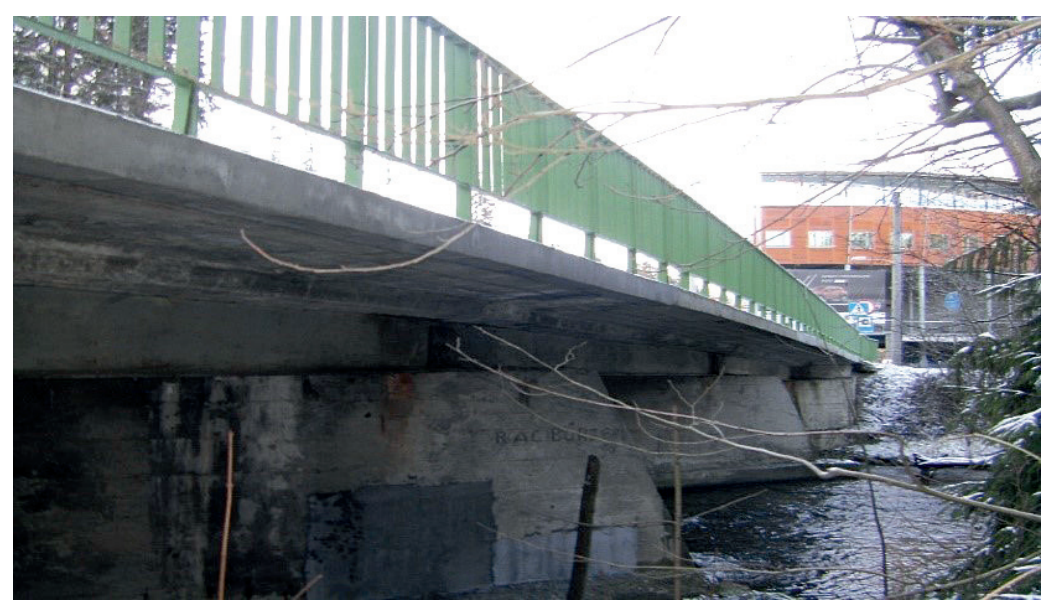

Fig. 1. The analysed bridge in Wisla (photo by authors)

a)

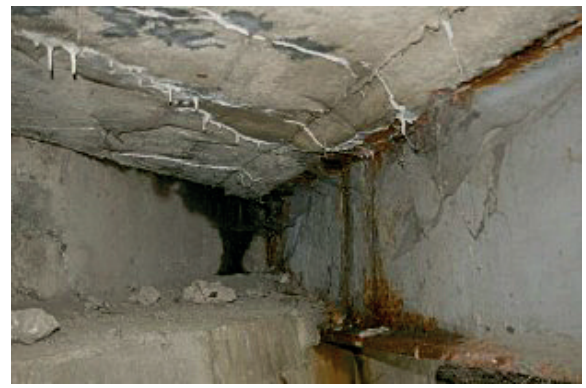

c)

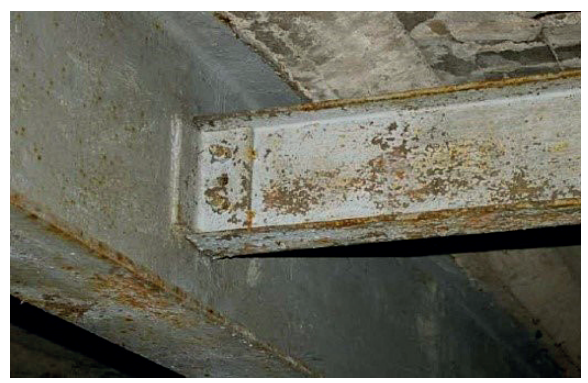

b)

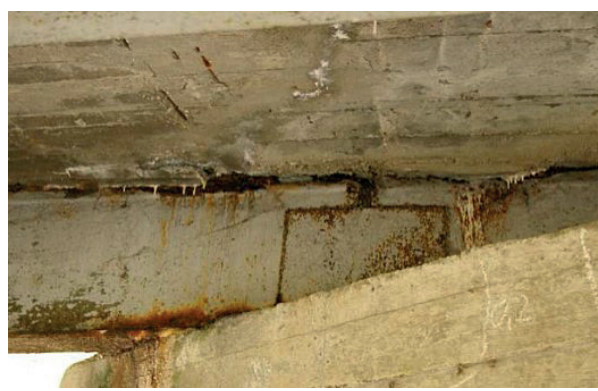

d)

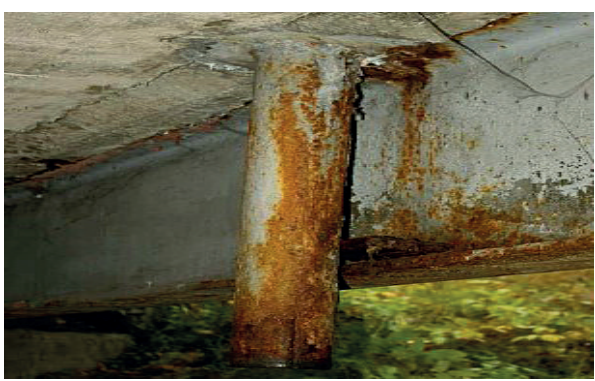

Fig. 2. a) Support of the extreme girder on the bridge abutment with corroded top and bottom flange;

b) The corroded steel girder is supported by bridge pillar; c) Corrosion of the connection between the cross beam and the main girder; $d$ ) Corroded drain pipe which forms part of the drainage system (photo by authors)

the reduction coefficients to the bearing capacity and durability of the analyzed object were taken into account and Tables 1 and 2 were developed. These values defined the percentage structural load bearing capacity decrease due to corrosion and the time between failures of the structure due to corrosion. 
Table 1. Data for the bearing capacity of the bridge in Wisla

\begin{tabular}{|c|c|c|c|c|c|}
\hline \multicolumn{7}{|c|}{ Reduction coefficient of load capacity } \\
\hline$u_{1}$ & $u_{2}$ & $u_{3}$ & $u_{4}$ & $u_{5}$ & $u_{6}$ \\
\hline 0.98 & 1.10 & 1.00 & 1.00 & 0.95 & 0.98 \\
\hline \multicolumn{6}{|c|}{ Load capacity decrease due to the bending moment } \\
Load capacity decrease due to the support reaction & $S_{M}$ & $7.36 \%$ \\
\hline \multicolumn{2}{|c|}{ Load capacity decrease of the solid web girder due to corrosion } & $S_{P}$ & $1.04 \%$ \\
\hline
\end{tabular}

Table 2. Data for the durability of the bridge in Wisla

\begin{tabular}{|c|c|c|c|c|c|c|}
\hline \multicolumn{8}{|c|}{ Reduction coefficient of durability } \\
\hline$S_{A}$ & $K_{R}$ & $T_{W}$ & $T_{i}$ & $T_{D}$ & $\beta$ & $W$ \\
\hline 0.98 & 0.923 & 0.98 & 0.90 & - & 0.96 & 54 \\
\hline \multicolumn{2}{|c|}{ Degree of shortening time between failures of structure } & $S_{T}$ & \multicolumn{2}{|c|}{0.850} \\
\hline \multicolumn{2}{|c|}{ Time between failures of structure due to corrosion } & $T_{e}$ & \multicolumn{2}{|c|}{27 years } \\
\hline
\end{tabular}

The analysis of the bridge in Wisla showed that the higher value takes the value of the load bearing capacity due to the bending moment than the value of the load bearing capacity due to the support reaction. The load bearing capacity decrease of the solid web girder due to corrosion was $7.36 \%$.The load capacity decrease of the bridge structure and time between failures of the structure due to corrosion depended on the type of corrosion located on the surface of girders. Additionally, the aggressiveness of the environment had the greatest impact on the durability of the bridge structure. The preceding analysis has shown that the time between failures of structure due to corrosion until this calculation was 27 years. This can only be good news for the functional longevity of this bridge. However, this method does not take into account the ongoing corrosion of the structure. The amount of corrosion very dynamically rises from year to year. The amount of corrosion products is increasing year by year due to the air pollution, the aggressive environment in which the bridge is located and the concentration and amount of salt used for the winter maintenance of roads. The corroded girders are damaged above the ultimate limit state and their durability has consequently been compromised. Therefore, this method allows estimation of the load bearing capacity and durability only with regard to the current state of the bridge structure.

\section{Conclusion}

The analytical method of estimating the effect of corrosion on the percentage loss in load bearing capacity and the time between failures of the bridge operation allows for easy and rapid determination of important parameters related to the strength and durability of steel bridge girders taking into account the destructive corrosion process. The use of this method is justified though the opportunity it presents to extend the functional longevity of the structure. The results of such an analysis constitute a valuable addition to the detailed 
reports of technical inspections of steel-concrete bridge structures. The results of this analysis enabled the determination of the approximate date for modernisation of the bridge and the development of a plan for renovation and technical improvement. This approach enables the identification of the loss of load capacity of bridges and the time between structural failures - this allows the formulation of optimal construction schedules for possible bridge are constructions. The preceding analysis document that the bridge located in Wisla does not require repair and reconstruction prior to the next detailed review. However, the technical condition of the bridge in Wisla should be monitored accurately during the ongoing reviews.

The research was supported by scientific grant SK-EN-2015-0004

\section{References}

[1] Janas L., Jarominiak A., Michalak E., Załacznik do Zarzadzenia nr 14 Generalnego Dyrektora Dróg Krajowych i Autostrad z dnia 7 lipca 2005r.Instrukcje Przeprowadzania Przegląów Drogowych Obiektów Inżynierskich, Warszawa, Wydawnictwo SIiTK RP, Oddział w Rzeszowie, Rzeszów 2005.

[2] PN-82/S-10052 Obiekty mostowe. Konstrukcje stalowe. Projektowanie.

[3] Czerepak A., Czudek H., Pryga A., Wysokowski A., Metoda szacowania wptywu korozji na nośność konstrukcji stalowych mostów drogowych. Zalecenia GDDKiA, Wydawnictwo IBDiM, Żmigród 2003.

[4] Chwastek A., Ulewicz M., Vician J., Assessing the corrosion impact on bearing capacity of steel girder bridges in Poland. Transcom Proceedings, $11^{\text {th }}$ European Conference of Young Researchers and Scientists, Section 7 Civil Engineering, Žilina 2015, 76-81.

[5] Wysokowski A., Limitation of corrosion effect on the reduction of load capacity of steel bridges by thermal spraying, Surface Engineering, No. 1, 2007, 39-47.

[6] Vičan J., Odrobiňák J., Steel structures, Wydawnictwo University of Žilina, Žilina 2008.

[7] Wysokowski A., Trwałość mostów stalowych w funkcji zjawisk zmęczeniowych i korozyjnych, praca habilitacyjna, Wydawnictwo IBDiM, Warszawa 2001.

[8] PN-EN 1993-2:2010 Eurokod 3. Projektowanie konstrukcji stalowych. Część 2: Mosty stalowe.

[9] Wawrzacz J., Kotowicz-Kulka K., Białecki T., Ocena aktualnej nośności wraz z raportem z przeglądu szczegółowego, Zarząd Dróg Wojewódzkich w Katowicach, Katowice 2010. 